\title{
A NEW SCELOPORUS MAGISTER FROM EASTERN UTAH ${ }^{1}$
}

\author{
WILMER W. TANNER
}

The analysis of the Desert Scaly Lizard, Sceloporus magister Hallowell, by Phelan and Brattstrom (1955), did not include a study of the populations of this species from the Upper Colorado River Basin of southeastern Utah. With a large series of this species available from Kane, Garfield, and Emery Counties, and with comparative material from Washington County, Utah, eastern Nevada, and California, it is apparent that the Upper Colorado River Basin populations represent a subspecies distinct from the populations of the southwest deserts.

\section{SCELOPORUS MAGISTER CEPHALOFLAVUS W. W. Tanner,} subsp. nov. ${ }^{2}$

Holotype: (An adult male) BYU 11270, collected at Bentley's Cabin, approximately 15 miles NW of Hole-in-the-Rock, Kaiparowits Plateau, Kane County, by D. Elden Beck, 16 July, 1953.

Paratypes: All numbers are from the Brigham Young University Collection. Emery County. - Green River, 531, 1780-1, 12445. Wayne County. - Notum, 11903. Garfield County. - Star Springs, Mt. Hillers. 12620, 13151, 13174; 20 miles NW of Hite (North Wash) 13153-66, 13174; two miles S. of Trachyte Creek 13167-72; Hog Springs, 14 miles NW of Hite, 12712-4, 12680-3. Kane County. Hole-in-the-Rock, 11400, 11263-4, 12885-6; Lone Rock, 11399, 12007, 13143-4, 13067; Catstair Canyon, 11392-8, 12845; Escalante River, lower portion, 9769, 11390; Coyote Gulch, 12947; Hall Cave, 123, 929-37; Willow Tank Spring, 115, 119, 901-5, 912-16, 4183-4, 11392-7; Wahweap Creek, upper portion, 2744, 2126-7, 2134-5.

Diagnosis: A Sceloporus magister characterized by the presence of five or six chevron shaped bars, $1 \frac{1 / 2}{2}$ to $21 / 2$ scales wide, on the dorsum from the shoulders to the base of the tail, in most adult males. Dorsal head plates and nape ranging from Apricot Yellow to Orange Chrome, Ridgeway (1912) in adults (male \& female). Eye stripe extended to ear or beyond, and with a second stripe extending from the corner of the mouth to the base of ear. Infralabials $6-8$, usually $7-7$; scales across the gular area 18-21, average 19.2.

Description of the type: Total length $222 \mathrm{~mm}$., snout to vent $104.5 \mathrm{~mm}$.; dorsal scales 36 , ventral scales 35 , scale rows around the body 34; femoral pores 12-12; gular scales between ears 19;

Contribution No. 149, Department of Zoology and Entomology.

2. The new name has reference to the yellow of the dorsal head plates and the nape in adults. 
supralabials 5-5, infralabials 7-8, enlarged auricular lobules 4-4; lamellae of fourth hind toe 17-17.

Coloration (in alcohol): Ground color approximately a BuffyBrown on body and head, nape a cream color, venter and throat black, chest and anal region Cartridge Buff; eye stripe distinct and extended three scales beyond top of ear, labial stripe from corner of mouth to base of ear; nape with two longitudinal stripes, approximately $1 \frac{1}{2}$ scales wide and extending for a length of 5 scales; gular patch joined to first chevron forming a collar $2 \frac{1}{2}$ scales wide at the dorsum; body with 5 chevrons, last two faint. Four lateral spots on each side, anterior ones faintly joined to chevrons; black on ventral surface of thigh approximates 60 per cent from inner margin of femoral pores to knee, black of belly extensive and united for 85 per cent of the area.

Range: Paria River drainage of central Kane County east to the Colorado River and north through eastern Garfield, Wayne, and Emery Counties, Utah. A small series from San Juan County approaches cephaloflavus closely as do those seen from Cameron, Coconino County, Arizona.

VARIATIONs: Although the basic body pattern of cephaloflavus consists of chevron shaped bars across the dorsum, this pattern is occasionally modified into a series of irregular spots, at times approaching the basic pattern of bimaculosus. The occasional spotted condition observed by Phelan and Brattstrom (loc. cit.) in uniformis of eastern Nevada and southwestern Utah represents intergradation between the latter and cephaloflavus. A series of adult males from the latter localities (see material) shows the chevron in three, spots in thirteen, and the uniform dorsum in four. Aside from the modifications in the basic patterns the most striking color variations, between uniformis (including the uniformis $x$ cephaloflavus intergrades of southwestern Utah and adjoining Nevada) and typical cephaloflavus is the yellowish-orange color in the latter. Adult males from California (uniformis) show a distinct series of four or five lateral spots separated by 1-2 scales. In cephatoflavus these spots are close together, often with two or three joined by one or more scales, and thus forming in some specimens an irregular lateral stripe. The belly patches, although varying as to the amount, are united in 78 per cent of the males studied.

Scutellation differences, though small, do exist in the increased gulars between the ears 18-21, average 19.2; and in the increased infralabials 6-8, average 7.05. Other scale counts are as follows: scale rows around body. 33-40, average 36.3; dorsals 31-36, average 33.6; ventrals 34-41, average 38.2; femoral pores $10-15$, average 12.6; lamellae of fourth hind toe 15-18, average 16.4. The circumorbitals are variable ranging from 3 to 8 , whereas the supralabials are constantly 5, rarely showing 4 or 6 .

Comparative material: All numbers are from the Brigham Young University Collection: - ARIZONA, Coconino County. 
Cameron, 13152; between Tuba City and Lee's Ferry, 639. Graham County: Ft. Thomas, 10267-71. CALIFORNIA, Los Angeles County. - 2 miles E of Littlerock, 13175; 3 miles E of Llano, 13176. San Benito County. - Panoche Valley, 8848. San Bernardino County. Cajon Pass, 11847. NEVADA, Clark County. - Horseshoe Island, Lake Meade, 2945, 3666-69. Lincoln County. - 16 miles W of Caliente, 9795-97, 9850; Crystal Springs, 10182-85. UTAH, San Juan County. - Bluff, 530, 1584, 1777-9; Montezuma Creek, 13177-9. Washington County - Cactus Flats, SW of Castle Rock, 2734, 3739, 8757; St. George, 495, 514, 1514, 1516, 1519, 8785, 10345, 11851, 1561-3, 1569-70, 1572, 1579, 1792-4; Berry Springs, 9718, 9772; Zion Nat'l. Park, 496, 1771-6, 3787, 11391.

Remarks: Insufficient material, from southeastern Utah and adjoining Arizona, Colorado and New Mexico, limits our understanding of the relationships of cephaloflavus and bimaculosus. It is apparent, however, that cephaloflavus is closely related to uniformis with which it is known to intergrade over a wide area in eastern Nevada and southwestern Utah.

\section{LITERATURE CITED}

Phelan, Robert L. and Bayard H. Brattstrom

1955. Geographic Variations in Sceloporus magister. Herpetologica 11: 1-14.

Smith, Hobart M.

1939. The Mexican and Central American lizards of the genus Sceloporus. Field Mus. Nat. Hist. Zool. Ser. 26: $1-397$. 


\section{$2 \mathrm{BHL}$ Biodiversity Heritage Library}

Tanner, Wilmer W. 1955. "A new Sceloporus magister from eastern Utah." The Great Basin naturalist 15, 32-34. https://doi.org/10.5962/bhl.part.14056.

View This Item Online: https://www.biodiversitylibrary.org/item/33384

DOI: https://doi.org/10.5962/bhl.part.14056

Permalink: https://www.biodiversitylibrary.org/partpdf/14056

\section{Holding Institution}

Harvard University, Museum of Comparative Zoology, Ernst Mayr Library

\section{Sponsored by}

Harvard University, Museum of Comparative Zoology, Ernst Mayr Library

\section{Copyright \& Reuse}

Copyright Status: In copyright. Digitized with the permission of the rights holder.

License: http://creativecommons.org/licenses/by-nc-sa/3.0/

Rights: https://biodiversitylibrary.org/permissions

This document was created from content at the Biodiversity Heritage Library, the world's largest open access digital library for biodiversity literature and archives. Visit BHL at https://www.biodiversitylibrary.org. 